\title{
EGÉSZSÉGPSZICHOLÓGIAI KUTATÁSOK ÉS AZ ALKALMAZOTT EGÉSZSÉGPSZICHOLÓGIAI ELLÁTÁS FEJLÔDÉSE AZ ELMÚLT 30 ÉVBEN MAGYARORSZÁGON
}

$$
\text { KÁLLAI JÁNOS }{ }^{1,2, *} \text { - URBÁN RÓBERT }{ }^{3} \text { - CSABAI MÁRTA }{ }^{4}
$$

${ }^{1}$ Pécsi Tudományegyetem Általános Orvostudományi Kar, Magatartástudományi Intézet, Pécs, Magyarország

${ }^{2}$ Pécsi Tudományegyetem Bölcsészet- és Társadalomtudományi Kar, Pszichológiai Intézet, Pécs, Magyarország

${ }^{3}$ Eötvös Loránd Tudományegyetem Pedagógiai és Pszichológiai Kar, Pszichológia Intézet, Budapest, Magyarország

${ }^{4}$ Szegedi Tudományegyetem Bölcsészettudományi Kar, Pszichológiai Intézet, Szeged, Magyarország

E-mail: janos.kallai@aok.pte.hu

Beérkezett: 2021. november 10. - Elfogadva: 2021. november 26.

A tanulmány az egészségpszichológia elmúlt évtizedekben Magyarországon lezajlott szakmai fejlôdését tekinti át. A programadó személyek felsorolása mellett részletesen tárgyalja a kutatási irányokat és az ellátási gyakorlat meghatározó eredményeit. Kiemelt figyelmet fordít a szakma specifikus fogalmainak bemutatására, a beavatkozások kompetenciaterületeire, valamint az egészségpszichológiai, a magatartás-orvoslás, a pszichoszomatika, a klinikai pszichológia területekkel való kapcsolatának értelmezésére. Bemutatja az új szakmai mentalitás és ellátási lehetôségek kialakulását, és ráirányítja a figyelmet az alkalmazott egészségpszichológiai ellátás és az egészségfejlesztés kiemelt fontosságú területeire, a társadalmi és mentális fejlódésben betöltött szerepükre. Továbbá szemelvényeket sorol fel a nemzetközi trendekhez való kapcsolódás kiemelkedô hazai eredményeirôl. Az egészségügyi finanszírozást és ellátást tervezố országos döntéshozók számára a testi, lelki és szociális egészség növelése érdekében javaslatokat fogalmaz meg az egészségpszichológiai ellátás fejlesztéséhez.

Kulcsszavak: egészségpszichológia, adherencia, rehabilitáció, rizikófaktorok, egészségfejlesztés

\footnotetext{
* levelező szerzó
} 


\section{BEVEZETÉS}

Az egészségpszichológia önálló tudományággá válása a nemzetközi trendekhez hasonlóan a hazai oktatásban és kutatásban egyaránt új fejlődési irányok kibontakozását tette lehetôvé. Az egészségpszichológiával is kapcsolatos szúkebb területek (orvosi pszichológia, klinikai pszichológia, pszichoszomatika, magatartás-orvoslás) neves hazai képviselôi (pl. Ádám György, Bagdy Emôke, Buda Béla, Császár Gyula, Grastyán Endre, Kopp Mária, Molnár Péter, Ozsváth Károly, Popper Péter) megágyaztak az új szakterület érkezésének. Az egészségpszichológia nemcsak új szemléletet és kutatási területeket hozott, hanem elôsegítette a pszichológia kapcsolódását más alap- és alkalmazott tudományokhoz úgy, mint például népegészségtan, epidemiológia, prevenciótudomány, egészségfejlesztés, klinikai orvostudományok. Az elmúlt harminc évnek kiemelt szerepe volt az egészségpszichológiai kutatások intézményes hátterének kialakulásában, a ma is aktívan múködô tanszékek és kutatócsoportok létrejöttében és a hazai egészségpszichológiai kutatás és gyakorlat nemzetközi láthatóságának megalapozásában.

Az egészségpszichológia szakirány a klinikai pszichológiával párosítva a budapesti, debreceni, pécsi és szegedi egyetemek pszichológia szakjainak fontos és egyben legnépszerúbb képzési területe. A társas erôforrás fejlesztésével és megôrzésével foglalkozó humán tudományok legkülönbözóbb képzési területein is a kurrikulum fontos részét képezi. A klinikai (alkalmazott) egészségpszichológia a szakpszichológia-tudomány és -gyakorlat egyik meghatározó területévé vált hazánkban is. A felsôfokú szakirányú szakképesítés megszerzésérôl szóló kormányrendelet (EMMI 22/2012. [IX. 14.]), valamint a szaktevékenység minimumfeltételeit leíró rendelet (EMMI, 28/2017./X. 25.) szerint a (71) kódot viselô szakpszichológia területei között az alkalmazott egészség-szakpszichológia külön számon (7108) szerepel. A megnevezett szakvizsgával rendelkezô szakemberek számára az egészségügyi törvény a szakorvosokéval megegyezó jogköröket biztosít. Az alkalmazott egészségpszichológia területén végzett szakpszichológusok gyógyszeres kezelést és gyógyszerfelírást ugyan nem végezhetnek, de önállóan betegeket fogadhatnak, delegálhatnak, terápiás beavatkozásokat végezhetnek, ügyeletet adhatnak. Szakmai kompetenciáik, az egészségügyi és más szociális szolgáltató intézményekben végzett szakképzésük és továbbképzési rendszerük megfelel a nemzetközi követelményeknek. Európai színvonalú tudományos felkészültségük és gyakorlati jártasságuk az egészségügyi ellátás, egészégfejlesztés valamennyi szintjén igénybe vehetô (alapellátás, kórházi és klinikai ambuláns és osztályos ellátás, közösségi és intézményes rehabilitációs szolgálatok, egészségneveléssel és pszichoszociális intervenciókkal foglalkozó intézetek, drogambulanciák, iskolai és munkahelyi egészségpszichológiai szolgálatok, graduális és posztgraduális oktatás és kutatás). Az egészségügyben alkalmazott egészség-szakpszichológus kontrollja mellett, az orvosi gyakornokok vagy rezidensek esetében megszokott eljárás szerint, egyes célfeladatok végrehajtásában szakvégzettséggel nem rendelkezô MA egyetemi végzettségú pszichológusok (szakpszichológus-jelöltek, rezidensek) is részt vesznek. Az alkalmazott egészség-szakpszichológus ráépített szakképzés keretében pszichoterapeuta szakképesítést is szerezhet.

Napjainkban az egészségpszichológia korábbi definíciója (Matarazzo, 1982) számos új területet magába foglalva kibôvült. Magyarországon az egészségvédelmi törek- 
véseknek köszönhetôen, a viselkedés- és kognitív terápiás rendszerre alapozott egészségügyi ellátás és az orvos-beteg között lévô kapcsolat fejlesztésén keresztül vált az egészségpszichológia a mindennapi egészségügyi ellátás és kutatási programok részévé. A teoretikus keretek tisztázása, a kompetenciahatárok meghatározása, a kutatási háttér és a beavatkozási módszerek graduális képzésbe integrálása meghatározó lépés volt a szakterület fejlôdésében (Bagdy és Telkes, 1988; Kulcsár, 1998; Bugán és Bartha, 2005; Kopp és Berghammer, 2005; Kállai, Varga és Oláh, 2007; Csabai és Molnár, 2009; Császár-Nagy, 2011; Urbán, 2017; Bárdos és Kraiciné Szokoly, 2018).

Magyarországon a mentális betegek kezelése és a mentális egészség megôrzése hoszszú és eredményes fejlôdési pályára tekinthet vissza. A 20. század elsô évtizedeiben a magyar pszichológia és pszichiátria és pszichoterápiás ellátás kiváló nemzetközi hírú elôdökkel büszkélkedhet. Ferenczi Sándor, Franz Alexander, Bálint Mihály, Császár Gyula (1989), továbbá Mérei Ferenc pszichodinamikus, tárgykapcsolati csoportterápiás munkái számos kaput nyitottak a gondolatok és érzelmek szabad kifejtéséhez. Az autonómia, a szabadság, a független véleményalkotás, a múlttal való ószinte szembesülés, a szimbólumok áttételein keresztül önmagát leleplezô személyes, de egyben mégis közös világ hiteles közeget biztosított a hazai betegellátás lélektani elemeinek fejlôdéséhez, jelentôs erôforrást biztosítva ezzel a késôbbiekben kifejlôdô terápiás irányokon keresztül az egészségpszichológia lendületes terjedésének. Az 1980-as évek elejétôl kezdve a kognitív és viselkedésterápia hazai térhódítása egyre több technikai lehetôséget biztosított a magatartás-orvoslás és késôbb az egészségpszichológia gondolkodásmód hazai terjedéséhez (Tringer, 1985; Perczel-Forintos és Mórotz, 2010). A történeti elôzmények alapján jól ismert, hogy a pszichodinamikus és tárgykapcsolati elméletek a korai fejlôdés idôszakában bekövetkezô pszichotraumákra vagy kapcsolati zavarokra vezetik vissza a gyermek-, kamasz- és felnôttkorban megjelenô tüneteket. A tünet a személyiségfejlôdést akadályozó pszichopatológia következménye, de egyben a rendellenesség tartóoszlopa is egyben. Az elmúlt évtizedekben jelentôs tudományos háttérrel megerôsített vélekedésekre, attitúdökre, a környezeti, testi és emocionális megnyilvánulások téves értelmezésén alapuló kognitív zavarokra összpontosító terápiás megközelítések a szomatikus betegségben szenvedó személyek egészségügyi ellátásában is új lehetôségeket teremtettek a pszichoszomatikus betegek, a mentális betegségben szenvedôk és általában az egészségügyi ellátást igénylô személyek kezelésében. A tünetek és a pszichopatológiai kórfolyamatok feltárása mellett a zavarok vagy a betegség tünetei által kiváltott szenvedés, a mentális és szociális nehézségek és a korlátozott lehetôségekbôl adódó hátrányok által okozott stressz a kórokok közé kerülve kiemelt figyelmet kaptak. Ez a gondolkodásmód a zavarok pszichopatológiai eredetét feltáró megközelítések ismerete mellett elsôsorban az aktuális gondolkodási formákra, a rizikófaktorokra, a perceptuális zavarok pillanatnyi kontextusára, a személy életvezetésére, gondolkodásmódjára, a társakkal való kapcsolatrendszer feltárására fordított jelentôsebb figyelmet. A pszichopatológiai folyamatok felismerésében és kezelésében jártas szakemberek jelentôs része ennek következtében új szemlélettel gazdagodott. A betegségben szenvedô személy aktuális igénye, betegségének lefolyása és életfeltételei figyelembevételével, ha úgy tetszik, pszichiátriai diagnosztikai kényszer nélkül, ezeket az elsôsorban nem pszichiátriai betegségben szenvedó személyeket eredményesen be lehetett vonni az egészégügyi ellátásba és az elsôdleges és harmad- 
lagos prevenció esetén felvetôdô problémák rendezésébe. A két megközelítési mód más vonatkozásban ugyanakkor nem különbözik számottevően egymástól. Mindkét fó kezelési irány a gyógyászatban követett gyakorlat szerint tudományosan igazolt, hatékony kezelési eljárásokat alkalmaz. Továbbá a pszichoterápiás gyakorlatnak megfelelôen a beteg ellátásának célja a személy testi, lelki és szociális jóllétének megteremtéséhez szükséges fejlôdési kapacitás növelése, a személy lehetôségei kibontakozásának elôsegítése, a jobb életminôség elérése személyes, családi, közösségi és társadalmi tekintetben egyaránt.

Az 1990-es évekre Magyarországon is kibontakozó egészségpszichológiai szemlélet, hazai betegellátási tapasztalatokkal gyarapodva markáns tudományos diszciplínává vált. Különösen az elmúlt évtizedben az egészségpszichológiai kutatások és a gyógyításban való aktív részvétel együttesen szolgálja a minôségi betegellátás érdekeit. Sok helyen azonban az igazolt és a betegek által is igényelt hatékony egészségpszichológiai ellátás finanszírozásának nem megfelelô mértéke részben akadályozza az ilyen irányú ellátás dinamikusabb fejlôdését. Az ellátás további fejlődésének támogatási módjáról a szakmai szervezeteink már kidolgozták a javaslataikat. Ennek néhány kiemelt fontosságú eleme a tanulmány végén megtalálható.

Az egészségpszichológia a tudományos kutatási eredményekbôl származó evidenciák alapján egészséges és különbözô mentális zavaroktól és betegségekben szenvedô személyeknél hozzájárul az egészséget megôrzô megfelelô életvitel kialakításához, a várható testi és lelki nehézségekkel szembeni küzdôképesség fejlesztéséhez, a betegségek megelőzését szolgáló tudatos közösségépítő és véleményformáló, a gyógyítást segítô és a rehabilitáció hatékonyságát növelô biopszichoszociális és spirituális fejlesztô tevékenység megalapozásához és kivitelezéséhez. Az egészégpszichológia törekvései szerint az ember természetes környezetében, gazdasági és szociális körülményei között, a humánökológia egységes rendszerének megvalósításán fáradozik. Következésképpen az egészségpszichológiai ismeretek alkalmazása az egészségügyi ellátórendszerek humánus múködtetésének és az egészségpolitikai tervezés megkerülhetetlen tényezôjének tekinthetô. A természeti, gazdasági és humán közösség által kialakított életfeltételeket az egészségpszichológia egységes rendszerben értelmezi. Az egészségpszichológia ökológiai szemlélete szerint az egészséges ember harmóniában van a természeti és az épített környezet egészével, szerves és alkotó részeként él együtt azzal. Az épített és természetes környezet tudatos gondozása és tisztán tartása, az erôforrások célszerú és takarékos felhasználása minden ember alapérdeke. A társas erôforrások jó hagyományokon, szakmai elveken nyugvó fejlesztése és funkcióképességének megôrzése a kultúra fejlődéstörténetének ismeretét feltételezô és azt támogató megfelelô gazdasági döntéseken is múlik.

Az egészségpszichológia múvelésének legaktívabb területei: a) Az egészségkárosító viselkedés, a betegséget okozó rizikófaktorok feltárására és elhárítására vonatkozó intervenciók kidolgozása és végrehajtása. b) Az egészség megôrzésére irányuló tudatos döntések elookészítése, a betegséggel összefüggô ellenálló képesség növelése, az úgynevezett viselkedéses „immunogénként szereplô” meggyôzôdések, vélekedések, szokások feltárása és bemutatása. c) Célcsoportok részére életminôség-fejlesztés, káros szokások feladásával kapcsolatos segítô beavatkozások és az egészségre vonatkozó pozitív attitúdök fejlesztése. Egészségre és betegségre vonatkozó nézetek, reprezentációk feltárása, 
szükség esetén azok módosítása. d) Kiélezett élethelyzetek által kiváltott stressz esetében a fejlôdést szolgáló hatékony megoldás, pszichoedukáció és egészségügyi, valamint személyes életvezetési stratégia megtervezésében való közremúködés: azaz a társas és személyes hatékonyság fokozása. e) Orvos és beteg együttmúködésének elósegítése a gyógyhatás fokozásának érdekében. A gyógyítás környezetének betegre és az ellátást végzô személyzetre gyakorolt hatásának elemzése az eredményesebb gyógyulási kimenetel elérése érdekében. f) Krónikus betegek, palliatív ellátásban részesülook, életvégi döntések előtt álló személyek és családtagjaik részére nyújtandó segítség. g) Primer, szekunder és tercier prevenció területén végzett hatékonyságvizsgálatok és a prevenció elókészítése és szervezése. h) Onkológiai, kardiovaszkuláris, gasztrointesztinális és különbözố szervtranszplantációs mútéteken átesett személyek gondozása, a pozitív kimenetelt elôsegítô kutatások és ellátásban való részvétel. i) Asszisztált in vitro fertilizációs eljárásban részesüló személyek elôkészítése, a kimenetelt befolyásoló pszichoszociális tényezôk vizsgálata és a felvetôdô pszichológiai nehézségek leküzdésében való terápiás részvétel. Az elmúlt években többek között a rizikóviselkedés, a közvetlen impulzusokkal szembeni kontrollvesztés, a pszichológiai immunrendszer, az autonóm emberek közösségére épülô társas és társadalmi szervezôdés, a betegségbôl való kilábalás pszichológiai mechanizmusai váltak az egészségpszichológia fó területeivé.

\section{ÚJ KÖVETELMÉNYEK ÉS LEHETŐSÉGEK}

Az egészség-, oktatásügyi és ipari alkalmazások területén az információtechnológiai fejlesztések új alkalmazásokat és ellátási módszereket igényelnek, melyek mindennapi „üzemmódban” és kritikus helyzetekben, katasztrófák, pandémiák esetében is megfelelô ellátást biztosítanak. A digitális környezettel kiegészülő gyógyítás a betegekkel való kapcsolattartás új formáinak alkalmazását teszi szükségessé. A beteg akár otthonában is használhat terápiás készülékeket, diagnosztikai érzékelôk kötik össze az egészségügyi intézmény informatikai fogadóhálózatával, távdiagnosztikai értékelésekkel segítik az esetek jelentôs részében krónikus betegségben szenvedô személyek ellátását. Az orvos az otthonában lábadozó beteget diagnosztikai és tanácsadó rendszerén keresztül bekapcsolja az ellátórendszer mindennapi körforgásába. A digitális rendszerekkel asszisztált egészségügyi hálózatok részben képzett szakértôként kezelik a beteget, bevezetik a gyógyítás kulcsfontosságú aktusaiba, és felkészítik ôt arra, hogy tájékozódjon, és aktívan alkalmazza a közösségi tudást a hatékonyabb gyógyulás érdekében. A kezelési folyamat módosításához kérdéseit mobiltelefonon, esetlegesen Skype-on vagy hasonló digitális alkalmazásokon keresztül is felvetheti. Az orvos virtuális jelenléte és az egészségügyi problémák szakértô megoldása a beteg privát életének mindennapos részévé válhat. Különösen igaz ez a krónikus betegek ellátásakor, kardiológiai leletek begyújtése, szomatikus állapotokat tükrözô paramétek otthoni rögzítése, munkahelyen végzett tevékenység során gyújtött adatok esetében. A gyógyászati technológiák és az online digitális hálózatok segítségével fenntartott személyes kapcsolat fejlôdése egyértelmúen jelzi az egészségvédelmi és a restoratív kompetenciák orvos és beteg közötti fokozatos megosztására való törekvést. Az orvos beavatja a betegét a gyógyítás folyamatába, és így a beteg az ellátás aktívabb szereplôjévé válik. Ez a beavatási el- 
járás a digitális hálózatokon sokszor ugyan ellenôrizetlen, de az orvosi tevékenységet érintố információk gyújtésének bôvülése révén számos elônyös lehetôséget tartalmaz. A betegnek a diagnosztikai és gyógyítási folyamatban való, megfeleló információkon alapuló személyes részvétele, adherenciája a hatékony gyógyítás legfontosabb eleme. A korábbi compliance-re, az engedelmes együttmúködésre épülô orvosi modell már csak bizonyos esetekben, a megfelelő tudatállapottal nem rendelkezô és fokozott dependenciát mutató betegeknél hozza meg a kívánt eredményt. Az egyéniség, a tájékozottság, az érdekérvényesítô képesség, a társas támogatás és a személyes biztonság, az emberi jogok tiszteletben tartása és annak kiharcolása, a döntési szabadság a pszichoszociális tényezôk fontos részeként a kezelés eredményességét befolyásoló tényezôk között kiemelt szerephez jut. Az orvos-beteg kapcsolatban bekövetkezô változás az ellátás módszereiben is érezteti a hatását. Felértékelôdnek a rendszerszintû diagnosztikai és kezelési módszerek, több diszciplína együttmúködésén alapuló, ugyanakkor mégis a beteg biológiai és pszichológiai egyediségére és lehetôségeire szabott ellátási formák. A beteg a saját tüneteit egyéni módon értelmezi, és a gyógyulás folyamatában is személyes ismeretei és vélekedései alapján vesz részt. A beteg tünetei mellett maga a beteg kerül a gyógyítás középpontjába: az egyénisége, a társak általi támogatottsága és a kritikus helyzetekkel kapcsolatos döntési képessége, a gyógyításban való felvilágosult részvétele. Minden ember szomatikus és pszichológiai fejlôdésének egyedi története van. A hatékony ellátás és kapcsolat kialakítása érdekében meg kell ismerni ezt a történetet. A gyógyítás eredményességének egyik fontos kimeneti mutatója, hogy a kezelôszemélyzetnek és a betegnek sikerült-e szót érteni egymással. A beteg ember egyre jobban igényli, hogy maga is (a lehetôségek szerint) részt vehessen a gyógyításban. Támogatandó törekvés! Ugyanakkor a saját egészségének védelméhez szükséges képességeknek és attitűdöknek, az egészséges táplálkozás módjainak, az egészség-magatartási alapismereteknek még a magyar társadalom jelentôs része nincs a birtokában.

Az infokommunikációs eszközök professzionális alkalmazása azonban segít a szélesebb körú és aktívabb egészségtudatos viselkedés kialakításában. Eredmény: kevesebb krónikus betegség, hosszabb és eredményesebb életpálya, a családra fordított anyagi és lélektani erôforrások növekedése. Ennek a folyamatnak fontos katalizátorai az egészségpszichológus és professzionális segítôi, a klinikai szakpszichológusok, akik a primer, szekunder és a tercier prevenció valamennyi szintjén testi és lelki eredetú betegségek esetén egyaránt az ellátás hatékony szereplői közé tartoznak.

A magyar lakosság az információtechnológiában lévő lehetôségek, élet- és gondolkodásmódra gyakorolt módosító hatások tekintetében még csak korlátozott lehetôségekkel rendelkezik. Sokan nem tudnak élni a kínálkozó elônyökkel, és nem ismerik fel az esetlegesen megjelenô kockázatokat. A mediált digitális felületek iránti kontroll nélküli elkötelezôdésük miatt gyakran nem ismerik fel az üzleti vagy más jellegú manipulatív szándékkal közölt megtévesztô ajánlatokat vagy üzeneteket. A digitális világhoz való kritika nélküli szenvedélyes kötôdés az egészségi állapot szempontjából is hordozhat veszélyeket. Az egészséges testi és lelki állapotért felelōsséget érzô szakmai közösségeknek tudatosan fel kell készíteniük a lakosságot a digitális eszközök használatára és a hatásmechanizmusuk természetére. Ekkor tudjuk érdemben a lakosság és a betegellátás számára szolgálatba állítani az egészégügyi szolgáltató és a beteg közé beépített digitális rendszereket. A felnôtt lakosság, fiatalok és gyermekek egészségügyi 
ellátásában az információtechnológia robbanásszerú fejlődése új eszközök szélesebb körû alkalmazását és új, hatékony és költségkímélôbb ellátási formák bevezetését kívánja egészség- és oktatásügyi intézmények számára egyaránt. A lakosság jelentôs része a digitális hálózaton keresztül szerzett információk birtokában felkészülten érkezik az egészégügyi ellátást végzô személyzettel való találkozásra. A beteggel való partneri kapcsolat esetén a szakember megfelelố csatornába terelheti vagy megerôsítheti a beteg aktivitása során szerzett információkat, és ezzel komoly mértékben növeli a betegségből való kilábalás esélyeit. Megfeleló tájékoztatás nyomán a segítségre szoruló aktívabban, személyes információk felhasználásával vesz részt a rehabilitációban és az egészségvédelmi programokban. A korábbi évekhez hasonlóan az egészségügyi szereplőknek fel kell készülniük a társas környezetben zajló gyógyítás és gyógyulás, betegségreprezentációk korrekciójára, a digitális eszközök használatára, a szerzett ismeretek megfelelő kritikus értékelésére és szükségszerúen azok megvitatására. Az elmúlt idôszak COVID-19-pandémia példája is mutatja, hogy a hatékony egészségügyi ellátás az emberek biztonságérzetének alapja. Tudni akarják, mi történik az ellátás során, és részt is kívánnak venni benne, hogy a bizonytalanság által kiváltott félelmeiken úrrá tudjanak lenni.

\section{FEJLESZTÉSI TÖREKVÉSEK AZ EGÉSZSÉGPSZICHOLÓGIÁBAN}

A magyar pszichológia itt nem részletezett kimagasló múltbeli és jelenlegi sikerei méltán figyelemre méltóak. A paradigma- és módszerváltozások, az egészségügyi ellátás és a betegek közötti érdemi és sikeres kapcsolatfenntartás és -fejlesztés során érdemes figyelembe venni ezt a jelentôs szakmai potenciált. Az egészséges társadalom egészséges közösségekből áll, amelyekben a formális és informális társadalmi csoportok és közösségek kapcsolata közös tiszteletre épül. Az egészségügyi ellátórendszer példamutatása jelentôs hatással van a közösségek egészséges múködésére és jóllétére. A kérdés az, hogy az egészségügyi ellátórendszer a betegségek gyógyítása mellett képes-e megvalósítani az egészséges társadalom megteremtésének misszióját. Ez a küldetés nemes, innovatív, de egyben költségkíméló és racionális feladat is egyben. Hazánk egyik legjelentôsebb erôforrása és fejlôdési lehetôsége a kimúvelt emberfô és az egészséges társas viszonyrendszer kiépítése. Az egészségügyben és oktatásügyben dolgozó és ezeket a társas tereket szervezó és finanszírozó szereplôk példamutatása kiemelkedô fontosságú az egészséges életforma, gondolkodásmód kihívásaihoz illeszkedô eszmény megvalósításában. Ezeket a gondolatokat a szakpszichológia és az egészségpszichológia szakmai álláspontjának alapjait biztosító biopszichoszociális és spirituális témakörben zajló tudományos vizsgálatok eredményei és sikeres nemzetközi példák támasztják alá.

Az egészségpszichológiai kutatások általában családi, társas, életmódbeli, fizikai és szociális lehetôségekból adódó környezeti hatások egyének és csoportok testi és lelki állapotra gyakorolt hatásainak tudományos eszközökkel történő feltárására összpontosítanak. A kutatások célja: fenntartani azokat a társas támogatásból származó elônyöket, melyek az egyénen túl egy társadalom egészének felemelkedését biztosítják. Ebból adódóan az erôforrások feltárása nem a pszichopatológiai zavarok enyhítése felól 
indul, hanem az egészséges lelkiállapot irányából közelíti meg a fejlesztési lehetôségeket. Vizsgálja: a mindennapokat kísérô egészséget veszélyeztetô tényezók jelenlétét, a betegséggel való küzdelem módját, a gyógyulás hatékony lélektani feltételrendszerét, a betegség felszámolásában részt vevô személyek hatékony együttmúködési lehetôségeit. Minden betegnek egyéni, megismételhetetlen élettörténete és élete során kialakított, rá jellemzó társas környezete van. Következésképpen a beteg gyógyítása ezen ismeretek birtokában személyes, fizikai és lélektani lehetôségeinek mozgósításával történhet a legeredményesebben. A betegséget nem a test hordozza, hanem a beteg ember. A gyógyítás a beteg és az orvos kölcsönös egymás iránti figyelme kíséretében, közös erőfeszítés alapján zajlik. Mindketten a maguk ismeretei alapján partnerek egy fontos feladat ellátásában, és közösen oldják meg a felvetôdô nehézségeket.

Az egészségpszichológusok az egészségügy, oktatás, mentális képességek fejlesztése, a hatékony életvezetés megórzése területen látnak el egyre szélesebb körú feladatokat. Az egészségpszichológia szemlélete szerint a betegség súlyos hátrányos hatásai ellenére magában hordozza a kilábalás által kínált új lehetôségeket is. Az életvezetés átértékelése új gondolkodásmód, hasznosabb szokások kialakítását is eredményezheti. A gyógyító beavatkozás irányvonala a személyiségfejlődés elôsegítése tekintetében egyértelmú. Túlmutat a tünetek megszúnésén. Elôsegíti az egészségtudatos életvitelt, a kreatív idôeltöltést és a családok és közösségek önszervezôdô kölcsönös támogatását. A spirituális mozgósító erô hatásait különösen az életet veszélyeztetô betegségek, különbözô típusú függôségek ellátása esetén kiemelt fontosságúnak tekinthetjük.

\section{KIEMELT TERÜLETEK}

Az ember szokásai és kultúrájának jelentôs része évezredes tapasztalatokkal, biológiai tényezőkkel összekapcsolódó, a fejlôdés menetében is követhetô történettel rendelkezik, aminek figyelmen kívül hagyása racionális gondolkodó részérôl nem lehetséges. Az egyed társas magatartását és viselkedéskontroll-képességét leginkább befolyásoló környezeti tényezôk emlôsök és humán egyedek vonatkozásában sok tekintetben hasonlóak (Dunbar, 2009). Következésképpen az egészséges mentalitás megtartása és fejlesztése, az egészségesen fejlôdô közösségek és társadalmak vezetôi számára a kultúra fejlôdésével kapcsolatos tudományos ismeretek figyelembevétele kötelezô érvényú. Az egészséges testi-lelki állapot kialakításának alapelvei kiállták az évezredek próbáját. Matarazzo (1982) és Rogers (1961) elméletei és az itt fel nem sorolt tudományos tényanyag, továbbá kultúrantropológiai ismeretek, transzperszonális vélekedések és spirituális hagyományok támasztják alá. A társas kooperatív törekvéseket a társas tevékenység értelmességébe vetett hit élteti. Tehát az a biológiai és történelmi tényeken alapuló felismerés, hogy az ellentétes vélemények szabad kifejtését követô, logikus érvelések után meghozott közös döntések képezik a közösségek fejlődésének központi erôforrását. A kooperáció folyamata feltárja, hogy a másik fél milyen mentális modellben gondolkodik, hogyan látja a világot, milyen preferenciái vannak. A kritika és a vélemények kifejtése, a vita során felvetôdô új szempontok elósegítik a konszenzus megteremtését, a vélekedôk többsége számára hiteles valóságkonstrukciót, az egészséges társas miliô megteremtését kínálják fel. Az egészségpszichológiai és általában a 
pszichoterápiás ellátásban is ezeket a szempontokat követik. Több évezredes humán és nonhumán tapasztalatok szerint az a közösség fejlôdik biológiai, szociális és lélektani értelemben a leghatékonyabban, amely az alábbiakban részletezett gyakorlatot követi:

- Az újszülöttet a közösség látványos ceremóniákat követve befogadja. A közösség tagjai önkéntesen szerepet vállalnak a gondozásban. A család tágabb környezete is lojális az anyával, aki önzetlen segítséget kap másoktól (altruizmus).

- A szociális élet közvetlen, barátságos, egyértelmú szabályokat követ, átlátható, érthetô és jól szervezett. A kapcsolatok észszerúek, a tulajdon szerzése és birtoklása transzparens (fegyelmezett, érthetô morális mintákat követ).

- A közösség tagjai napi kapcsolatban vannak, közös programokat szerveznek. Megosztják használati eszközeiket, értékeiket, és bizonyos feltételekkel a tulajdonukat. Közös játékokban vesznek részt, és közösen szórakoznak, begyakorlott szokásokat követnek (együttmúködés).

- A közösségen belüli agressziót tiltják, a megosztottságra való törekvést és a félelemkeltést elutasítják (szolidaritás).

- A párkapcsolatok kialakítása egyértelmú szabályok szerint zajlik (konvenciókon alapuló párkeresési stratégiák).

- Figyelnek egymásra, a rászorulókat támogatják és önzetlenül gondozzák (tisztelet és megbecsülés).

- Viselkedésük során a vágyak megvalósításának morális kontrollja miatt tiszteletben tartják a másik elzárkózását, egyedi igényeit, individualitását (tolerancia, autonómia).

- Elvetik a hatalmi arroganciát (demokratikus problémakezelés).

- Feladatorientált, nem kirekesztô koalíciókat hoznak létre. Elfogadott problémamegoldási stratégiákat, sikeres viselkedésmodelleket követnek (célvezéreltség).

- Boldog az a közösség, melynek tagja ôszinte önmagával és másokkal, mert érti azokat a szabályokat, amelyek alapján önmaga viselkedik, és amelyek szerint mások tevékenykednek, aki kitart transzperszonális céljai megvalósítása mellett még akkor is, ha alkalmanként üldözötté válik, kigúnyolják, mert tudja, hogy jó ügyet szolgál (transzperszonalitás).

A hazai egészségpszichológia fejlôdése követi a biopszichoszociális és spirituális fejlôdés nyomvonalát (Kulcsár, 1998, Kiss és Sz. Makó, 2018; Bugán, 2017), érzékenyen reagál különbözô élethelyzetben, betegségekben és fejlődési életszakaszban lévô emberek igényeire. Az elmúlt évtizedben felismerve a közösségi betegellátás és gyógykezelés által felvetett igények fokozódását, az egészségpszichológia számos újdonsággal, szakmai szervezeti fejlesztéssel, kutatási eredményekkel, klinikai innovációkkal, közösségfejlesztési javaslatokkal és programokkal járult hozzá a magyar testi és lelki egészségi állapot javításához. A teljesség igénye nélkül az alábbiakban néhány friss példát említünk az eredmények közül.

- Az ELTE-n Kulcsár Zsuzsanna professzor és kollégái (Rigó Adrien, Urbán Róbert) szervezésében megindult az egészségfejlesztô szakpszichológus szakirányú továbbképzés az országban elôször. Bár ez a képzés úgy indult meg, hogy a társadalom még nem ismerte fel a pszichológusok szerepét az egészségfejlesztésben, újabban érdeklốdés mutatkozik az ilyen irányú szakmai továbbképzések iránt. 
- 2012-ben az alkalmazott egészség-szakpszichológiai szakpszichológus szakképzés széles körú szakmai támogatással megkapta az akkreditációt, majd 2013-ban a Szegedi Tudományegyetem szervezésében elindult a képzés (szakmai vezetô: Csabai Márta), melyben a kezdetektôl részt vesznek oktatóként a hazai egészségpszichológia meghatározó képviselôi a társegyetemekrôl.

- A Szegedi Tudományegyetemen a klinikai fekvô- és járóbeteg-ellátás számára kidolgozták az egészségpszichológia ellátási modelljét, és ehhez kapcsolódóan módszertani fejlesztések is történtek (Csabai és Pintér, 2013).

- 2013-tól kezdôdôen több országos alapellátási fejlesztési program zajlott klinikai és egészségpszichológus szakértốk bevonásával, melyekben hangsúlyosan szerepelt a pszichológusok (klinikai, egészség- és más szakterületek) részvétele a háziorvosi ellátásban (Svájci-magyar alapellátás fejlesztési modellprogram, EFOP 1.8.0 Krónikus gondozás az alapellátásban).

- Szakmai ajánlások készültek az EMMI számára a mindennapos testnevelés érzelmi és kognitív fejlesztést célzó, a testi-lelki egészég megôrzését támogató programjához (budapesti, debreceni, pécsi, szegedi magatartás-tudományi intézetek közremúködésével).

- A káros szokásviselkedések megfékezésérôl szóló, elsôsorban a dohányzásról való leszokás és a dohányzás ártalmas hatásait bemutató kampány és országos prevenciós program benyújtása az EMMI részére. Továbbá mivel a dohányzás kiemelt népegészségügyi probléma, hazai egészségpszichológusok is részt vesznek a dohányzással kapcsolatos kutatásokban a nemzetközi trendekbe bekapcsolódva (pl. Urbán, 2010; Nădășan és mtsai, 2016).

- A magyar egészségpszichológiai ellátás fejlesztése érdekében benyújtottuk a fejlesztés, a szervezeti és finanszírozási feltételek magasabb szintú biztosítása érdekében készült javaslatainkat az EMMI számára (Egészségügyi szakmai irányelv a szakpszichológiai ellátásról. Azonosítószám: 002182 közlése folyamatban, Kovács és mtsai, 2021).

- Az egészségügy és az oktatási gyakorlat is nyit a virtuális valóságok és a digitális technológiák felhasználása irányába. Ezek egészségpszichológiai sajátosságairól nemzetközi példákat is soroló részletes összefoglaló is készült (Kállai, 2022).

- A Kopp Mária kezdeményezésére évtizedekkel ezelőtt indult Magyar lelkiállapot vizsgálatnak elkészült a következô eredményközlő kötete (Susánszky és Szántó, 2013).

- 1985 óta folyamatosan zajlik az Iskoláskorúak Egészségmagatartásának vizsgálata (HBSC) nemzetközi együttmúködés keretében, aminek a legutóbbi beszámolója (Németh és Várnai, 2019) nemrég jelent meg, iránymutatást adva a lehetséges fejlesztési irányokhoz.

- Új eredmények születtek a sebészeti ellátás területén, melyek közül példaként említhetôk a veseátültetés eredményességét befolyásoló és a szerv testképbe integrálásával kapcsolatos eredmények (Látos és mtsai, 2015). Ezek számos krónikus betegség ellátásában vetnek fel új lehetôségeket.

- A nemzetközi standardokat követô kardiovaszkuláris rehabilitáció eredményességét befolyásoló társas támogatás és diétás táplálkozás elfogadásának feltételrendszere (Teleki és mtsai, 2019). 
- A Nemzeti Szívprogram keretében a kardiovaszkuláris betegségek pszichoszociális kockázati tényezőinek felmérésére kidolgozott standardizált eljárás (Martos és mtsai, 2020).

- Ígéretes eredményeket hozott az in vitro fertilizáció eredményességét befolyásoló pszichológiai tényezók felderítése (Nagy és Nagy, 2016), tovább gazdagítva ezen a területen a fejlôdési lehetôségeket.

- Egészségpszichológiai alapkutatásként a placebo (Köteles, 2013) és a modern egészségi szorongások (Köteles és Simor, 2013) területén Köteles Ferenc és Bárdos György nemzetközileg is elismert eredményei rámutattak a gyógyítás nemspecifikus mechanizmusainak egy csoportjára, valamint a modern technológiai környezet okozta szorongások jelentôségére. A pszichofiziológiai kutatócsoportjuk jelenleg az interocepció kutatásában mutat fel újabb eredményeket.

- Szabó Attila a testedzés és a versenysport kedvezó és kedvezótlen aspektusainak kutatásával az egészségpszichológia, az addiktológia és a sporttudomány határterületén egyaránt jelentôs nemzetközi elismertséggel bír (pl. Egorov és Szabó, 2013; Kovacsik, Soós, De la Vega, Ruíz-Barquín és Szabo, 2020; Szabo és Tsang, 2003).

A fentiekben említett jelentôs szakmai érdemek és hatékonyság ellenére az elmúlt évtizedekben az egészségügy korlátozott mértékben élt a szakmai közösség által biztosított kompetenciákkal. A tevékenységfinanszírozás alacsony értékei miatt az osztályos és ambuláns, továbbá a közösségi szférában dolgozó rehabilitációs és tanácsadói, egészségpszichológiai és prevenciós területek nem kapták meg azt a támogatást, amely elôsegítette volna ezen ellátási formák szélesebb körú alkalmazását, gyógyászati centrumokhoz köthetô fejlődését.

\section{LEHETÔSÉGEK AZ EGÉSZSÉGPSZICHOLÓGIA, A TESTI, LELKI ÉS SZOCIÁLIS EGÉSZSÉG FEJLESZTÉSÉRE, A TÁRSSZAKMÁKKAL KARÖLTVE}

Az egészségpszichológiai ellátás egyik legfontosabb célja a betegségek kialakulását elōsegítô és a társas fejlôdést akadályozó családi kapcsolatokban lévô zavarok feloldása (szerep, feladatmegosztás, problémamegoldás, személyes törekvések egyeztetésének zavarai). A gyermekek neveltetési körülményeibôl származó biztonsághiány, szorongás, a társas adaptációt súlyosan hátráltató társas és iskolai ismeretek hiányosságai szintén kockázati faktorok a betegségek megjelenésében. A felsorolt zavarok miatt nagy számban esnek ki felnôttek a munkából, gyermekek maradnak távol az iskolától. A zavarok következményeként sokan hordoznak hibás konfliktusmegoldási módokat és egészségkárosító kockázatokat. A drog, dohányzás és egyéb, függốséget okozó magatartás, antiszociális viselkedés, iskolai és családon belüli erôszak destruálja a biztonságos környezetben való hitet és a társas alkalmazkodás szempontjából kedvezô testi és lelki stabilitást, a szociálisan értékes célok kitûzését és az azok eléréséhez szükséges kitartást és a támogató társas közeg felépítését.

A szociális és társas konfliktusokat fokozó környezet egészségügyi kockázatokat eredményez. A társas és anyagi lehetôségek feletti kontroll elvesztése komoly szorongást kiváltó tényezô. A kezeletlen szorongás elôbb vagy utóbb egészségromláshoz, súlyos 
viselkedészavarokhoz, szerekkel való visszaéléshez vezet. A megfelelô idôben érkezô szakpszichológiai beavatkozás jelentôs hatású, lassítja a súlyos betegségek hátrányos kimenetelét, növeli a társas támogatást, a kezelô személyzettel az együttmúködést, és ezen keresztül növeli a személyes és társas erôforrásokat, mely mutatók közismerten a betegségekkel szembeni küzdelem és a prevenció szempontjából is a legfontosabb támogató tényezók.

Az alapellátásban megjelenô valamennyi krónikus betegség kóroktana tartalmaz pszichoszociális zavarokat, melyek a kezelés különbözó fázisaiban eltérô súllyal vannak jelen. Az érintett egészségügyi problémák ellátásában a biopszichoszociális kezelési módokat követô pszichológusok szerepvállalása kifejezett haszonnal jár. A krónikus betegek ellátásának terhe az egészségpszichológusok (és általában a szakpszichológusok) bevonásával csökkenthetố, a kedvezố kimenetel fokozható. Az alvászavarok, alkoholproblémák, hátrányos életvezetési szokásokkal rendelkezô, táplálkozási zavaroktól szenvedô, kardiovaszkuláris, gasztrointesztinális zavarokkal küzdô személyek ellátása során alkalmazott szokásviselkedés, rizikóelemzés, kontrollképességet fejlesztô lélektani eljárások, valamint a szükség szerint végzett pszichoterápiás beavatkozások növelik a beteg adherenciáját, és kedvezőek a krónikus betegségból származó szomatikus és társas hátrányok csökkentésében.

Tanácsadó egészségpszichológiai szolgálatok tevékenysége gyermeknevelés, újszülöttek fogadása, terhességvállalás, családi és párkapcsolati zavarok, fejlôdési krízisek vezetésében primer és szekunder prevencióban nem nélkülözhetô. Ezek a szolgálatok ismerik a helyi közösségeket. Az egészségvédô és társadalmi egészségkrízisek és szúrôprogramok esetében az érintett lakossági csoportokkal való közvetlen kapcsolattartáson keresztül végezhetik a munkájukat. Minden problémát ott kell megoldani, ahol az keletkezik, mielôtt még nagyobb nehézséget okozna. Ezeket a problémákat hatékonyan a moderátorok, az adott közösséget jól ismerô szakemberek tudják eredményesen kezelni.

Külön gondot érdemes fordítani a hátrányos anyagi és szociális helyzetben élô személyek egészséglélektani és kognitív fejlesztésére. Az információs technológia fejlôdése következtében olyan kihívások elốtt áll az egészség- és az oktatásügy, mely mediátorok alkalmazásának elmaradása fejlődési lemaradásokat fog okozni. Ezeknek a problémáknak a csillapítására az egyik legautentikusabb lehetôség a professzionális tanácsadó szolgálatok alkalmazása. Külön jelentôsége van a központoknak a halmozott hátrányokkal küzdô régiók fejlesztésében. Célszerú lenne tehát nagy kapacitású egészségpszichológiai és szakpszichológiai tanácsadó központokat létrehozni, melyek egy-egy egyetemi bázishoz kapcsolódva az alapellátáshoz is illeszkedô tudástranszferrendszert biztosíthatnak az új technikai és társadalmi szociális változásokkal való megküzdéshez.

Az egészségfejlesztô központok létrehozásához szükséges lépések:

- Az egészségügyi intézményekben múködô osztályos, ambuláns ellátás, az egészségpszichológiai prevenció és tanácsadás HBCS finanszírozásának jelentôs emelése.

- A fejlesztéshez szükség van a TB által finanszírozott szakpszichológiai álláshelyek számának növelésére. 
- Regionális hatáskörú egyetemi közegbe ágyazott szakpszichológiai tevékenységet végzô Lelki Egészségfejlesztô Központok (EFK) létrehozására van szükség, melyekhez a lakosság alapellátáson keresztül, de tanácsadási igény esetén attól függetlenül is hozzáfér. Lényege, hogy a medicinális és szociális szféra között önálló professzionális szereplóként van jelen. Nem tartozik pszichiátriai intézményhez sem, de az EFK egészségügyi intézményként közvetlen kapcsolatban van vele. Nem tartozik az önkormányzati szociális ellátórendszerhez sem, de eleven kapcsolatot ápolnak egymással.

- A regionális hatáskörú szakpszichológiai tevékenységet végző csoportok részt vehetnek: a szakoktatásban, szûrôvizsgálatok egészségpszichológiai népszerúsítésében, testi és mentális egészségállapothoz kötött (iskolai, munkahelyi) és veszélyeztetett csoportok pszichoedukációjában, esetlegesen felvetôdó lelki zavarok esetén a megfelelô betegutak kijelölésében, a reszocializációs és a kezelést követô mentális és kognitív rehabilitációs programok megszervezésében.

\section{IRODALOM}

Bagdy, E., \& Telkes, J. (1988). Személyiségfejlesztố módszerek az iskolában. Budapest: Tankönyvkiadó.

Bárdos, Gy., \& Kraiciné Szokoly, M. (2018). Egészség, életmód, egészségfejlesztés a felsôoktatás szemszögéböl. Neveléstudomány: Oktatás - Kutatás - Innováció, 6(2), 5-21.

Bugán, A., \& Bartha, A. (2005). A Debreceni Egyetem Pszichológiai Intézetében folyó egészségpszichológiai kutatások. Alkalmazott Pszichológia, 7(1), 162-173.

Bugán, A. (2017). Pszichológiai szolgáltatások az alapellátás szintjén. In R. Ádány, \& M. Papp (Ed.), Prevenciós szolgáltatások az alapellátásban (pp. 327-348). Budapest: Medicina Könyvkiadó.

Csabai, M., \& Molnár, P. (2009). Orvosi pszichológia és klinikai egészségpszichológia. Budapest: Medicina Könyvkiadó.

Csabai, M., \& Pintér, J. N. (Ed.) (2013). Pszichológia a gyógyításban - Fenomenológiai, múvészetpszichológiai és testképközpontú megközelitések. Budapest: Oriold és Társai.

Császár, Gy. (1989). Pszichoszomatika a gyakorlatban. Budapest: Pszichoteam Kiadó.

Császár-Nagy, N. (2011). A krónikus fájdalom biopszichoszociális megközelítése és kezelése. In Császár-Nagy, N., Demetrovics, Zs., \& Vargha, A. (Eds), A klinikai pszichológia horizontja. Budapest: Károli Könyvek.

Kállai, J. (2022, in press). Számítógép által létrehozott virtuális valóság pszichológiai mechanizmusai: egészség-és oktatásügyi alkalmazások. Budapest: Medicina Kiadó.

Kiss, E. Cs., \& Sz. Makó, H. (2018). Gyász, trauma, krízis és a megküzdés lélektana. Pécs: Pro Pannonia Kiadó.

Kovács P., et al. (2021). Emberi Erőforrások Minisztériuma. Egészségügyi Szakmai Kollégium. Egészségügyi szakmai irányelv - A szakpszichológiai ellátásról. Egészségügyi Közlöny (in press)

Köteles, F. (2013). A placebo-válasz. Budapest: Medicina.

Tringer, L. (1985). Klinikai viselkedésterápiák. Budapest: MPT.

Urbán, R. (2017). Az egészségpszichológia alapjai. Budapest: ELTE Eötvös Kiadó 


\section{Szemelvények az empirikus tanulmányok sokaságából}

Csabai, M., \& Papp-Zipernovszky, O. (Eds) (2015). Gyógyítók egészsége: A hivatás kihívásai és a változás lehetôségei. Budapest: Oriold és Társai Kiadó.

Egorov, A. Y., \& Szabo, A. (2013). The exercise paradox: An interactional model for a clearer conceptualization of exercise addiction. Journal of Behavioral Addictions, 2(4), 199-208.

Hock, M., Farkas, N., Tiringer, I., Gitta, S., Németh, Z., \& Farkas, B. (2019). Validation and translation of the Hungarian version of the Female Sexual Function Index (FSFI-H). International Urogynecology Journal, 30(12), 2109-2120.

Kállai, J., Barabás, K., Túry, F., Csabai, M., \& Molnár, P. (2018). Az orvosi pszichológia fejlôdése hazánkban: szemléleti keretek, határterületek és alkalmazások. Orvosi Hetilap, 159(36), $1455-1464$.

Köteles, F., \& Simor, P. (2013). Modern Health Worries, Somatosensory Amplification and Subjective Symptoms: A Longitudinal Study: A Longitudinal Study. International Journal of Behavioral Medicine, 20(1), 38-41. DOI: https://doi.org/10.1007/s12529-011-9217-y

Kovacsik, R., Soós, I., De la Vega, R., Ruíz-Barquín, R., \& Szabo, A. (2020). Passion and exercise addiction: Healthier profiles in team than in individual sports. International Journal of Sport and Exercise Psychology, 18(2), 176-186.

Látos, M., Devecsery, Á., Lázár, Gy., Horváth, Z., Szederkényi, E., Szenohradszky, P., \& Csabai, M. (2015). The role of body image integrity and posttraumatic growth in kidney transplantation: A 3-year longitudinal study. Health Psychology Open, Paper: 2055102915581214.

Martos, T., Csabai, M., Bagyura, Zs., Ocsovszky, Zs., Rafael, B., Sallay, V., \& Merkely, B. (2020). Cardiovascular disease risk perception in a Hungarian community sample: psychometric evaluation of the ABCD Risk Perception Questionnaire. BMJ Open, 10(7), Paper: e036028.

Matarazzo, J., D. (1982). Behavioral health's challenge to academic, scientific, and professional psychology. American Psychologist, 37, 1-14.

Nădăşan, V., Foley, K. L., Pénzes, M., Paulik, E., Mihăicuță, Ş., Ábrám, Z., et al. (2016). The Shortterm Effects of ASPIRA: A Web-based, multimedia smoking prevention program for adolescents in Romania: A cluster randomized trial. Nicotine \& Tobacco Research, 19(8), 908-915.

Nagy, E., \& Nagy, B. (2016). Coping with infertility: Comparison of coping mechanisms and psychological immune competence in fertile and infertile couples. Journal of Health Psychology, 21(8), 1799-1808.

Németh, A., \& Várnai, D. (2019). Kamaszéletmód Magyarországon. ELTE PPK. L’Harmattan Kiadó Budapest.

Szabo, A., \& Tsang, E. (2003). Motivation for increased self-selected exercise intensity following psychological distress: Laboratory-based evidence for catharsis? Journal of Psychosomatic Research, 55(2), 133.

Teleki, Sz., Zsidó, A., Komócsi, A., Lénárd, L., Kiss, E. Cs., \& Tiringer, I. (2019). The role of social support in the dietary behavior of coronary heart patients: an application of the health action process approach. Psychology Health \& Medicine, 24(6), 714-724.

Urbán, R. (2007). A dohányzás egészségpszichológiája. Budapest: Nyitott Könyvmúhely Kft.

Urbán, R. (2010). Smoking outcome expectancies mediate the association between sensation seeking, peer smoking, and smoking among young adolescents. Nicotine \& Tobacco Research, 12(1), 59-68.

\section{Összefoglalók és tankönyvek az egészségpszichológia területérôl}

Bárdos, Gy. (2003). Pszichovegetatív kölcsönhatások. Budapest: Scolar.

Csabai, M. (2007). Tünetvándorlás. A hisztériától a krónikus fáradtságig. Budapest: Jószöveg Múhely Kiadó. 
Demetrovics, Zs., Urbán, R., Rigó, A., \& Oláh, A. (Eds) (2012). Az egészségpszichológia elmélete és alkalmazása I-II. Budapest: ELTE Eötvös Kiadó.

Hevesi, K., Urbán, R., \& Rigó, A. (Eds) (2020). Szexuálpszichológia. Budapest: ELTE Eötvös Kiadó.

Horti, J., \& Riskó, Á. (Eds) (2006). Onkopszichológia a gyakorlatban. Budapest: Medicina Kiadó.

Hoyer, M. (2006). A tárgy titokzatos vágya: avagy a család szerepe a sóvárgás (craving) kialakulásában. Psychiatria Hungarica, 21, 56.

Kállai, J., Varga, J., \& Oláh, A. (Eds) (2007). Egészségpszichológia a gyakorlatban. Budapest: Medicina Könyvkiadó.

Kállai, J., Kaszás, B., \& Tiringer, I. (Eds) (2013). Az idôskorúak egészségpszichológiája. Budapest: Medicina Kiadó.

Kopp, M., \& Berghammer, R. (Eds) (2005). Orvosi pszichológia. Budapest: Medicina Kiadó.

Kulcsár, Zs. (1998). Egészségpszichológia. Budapest: ELTE Eötvös Kiadó.

Oláh, A. (2005). Érzelmek, megküzdés és optimális élmény. Budapest: Treffort Kiadó.

Perczel-Forintos, D., \& Mórotz, K. (2010). Kognitív viselkedésterápia. Budapest: Medicina Kiadó.

Susánszky, É., \& Szántó, Zs. (2013). Magyar lelkiállapot 2013. Budapest: Semmelweis Kiadó.

Urbán, R. (2017). Az egészségpszichológia alapjai. Budapest: ELTE Eötvös Kiadó.

\title{
THE LAST 30 YEARS IN THE DEVELOPMENT OF HEALTH PSYCHOLOGY IN HUNGARY: RESEARCH AND CARE
}

\author{
KÁLLAI, JÁNOS - URBÁN, RÓBERT - CSABAI, MÁRTA
}

The study overviews the development of health psychology in Hungary for the last decades. Besides of the list of the progenitors confers in detail about the research lines and the relevant results of the care and practice. It pays attention to the introduction of the profession-specific concepts and the competence areas of the interventions, furthermore the interpretation of the relationship between health psychology, behavioral medicine, psychosomatic medicine, and clinical psychology. Presents the new mentality and form of care and highlights the role of the significance of applied psychology and health development in social and mental advancement. Furthermore, specifies a collection from the Hungarian outstanding research data related to relevant international trends. The study contains some proposal for the governmental decision-makers that provides a chance for the health psychological services to develop better bio-psycho-social health in our country.

Keywords: health psychology, adherence, rehabilitation, risk factors, health development

A cikk a Creative Commons Attribution 4.0 International License (https://creativecommons. org/licenses/by/4.0/) feltételei szerint publikált Open Access közlemény, melynek szellemében a cikk bármilyen médiumban szabadon felhasználható, megosztható és újraközölhetô, feltéve, hogy az eredeti szerzô és a közlés helye, illetve a CC License linkje és az esetlegesen végrehajtott módosítások feltüntetésre kerülnek. (SID_1) 